\title{
The Internet and International Trade in Services
}

\author{
By Caroline Freund and Diana Weinhold*
}

The scope for growth of trade in services is vast. Although services currently make up over 60 percent of world production, they account for only about 20 percent of world trade. A primary reason why international trade in services has been limited is that the performance of many services necessitates physical contact between producers and consumers, a condition that renders service provision to distant locations infeasible. New technology, in particular, the Internet, provides a medium of exchange that overcomes such historical trading hurdles for many services, effectively reducing transport costs from infinity to virtually nothing.

There is ample anecdotal evidence that the Internet is having just this sort of an effect on services trade. The accounting firm Netlink maintains the books for 6,000 employees in Reyanosa, Mexico, from their offices in Manhattan. Infosys of India provides softwareconsulting services to international clients, including Apple Computers, Lucent Technologies, and Microsoft. A medical-transcription company in South Africa, ITS, receives digital recordings from abroad electronically and returns a transcribed text file the next day.

Still, the question remains as to whether electronic sharing of information is an important enough development to alter significantly the geography of service provision. Indeed, many services need to be tailored to the consumer's needs and monitored for quality, and these are likely to be more effective if the provider is close by and speaks the same language. In addition, in the event of a dispute, resolution will be less complicated if both parties are subject to the same legal system. Finally, there may be security concerns with allowing foreign access to some documents or systems. Thus, for some services, especially those where familiarity,

\footnotetext{
* Federal Reserve Board, Washington, DC 20551, and Development Studies Institute, London School of Economics, Houghton Street, London WC2A 2AE, respectively. We thank Beth Allen, Simeon Djankov, Hali Edison, Jane Ihrig, and Andrew Levin for comments.
}

communication, and non-standardization contribute to quality, the Internet would not be expected to have a large impact on international trade.

To determine whether the Internet has significantly affected international service provision in practice, we estimate a general model of services trade across countries and examine whether the inclusion of data on Internet penetration, as measured by the number of Internet hosts in a country, is statistically significant. Overall, our results offer evidence that the Internet is related to growth in services trade. After controlling for GDP and exchange-rate movements, we find that a 10-percent increase in Internet penetration in a foreign country is associated with about a 1.7-percentage-point increase in export growth and a 1.1-percentagepoint increase in import growth. The results are robust to a number of alternative specifications.

\section{Data on Services Trade and the Internet}

We focus our discussion on U.S. trade data, as there are no comparable bilateral services trade data across countries. International trade in services is strongly dominated by the United States, which traded over $\$ 500$ billion worth of services in 2000. We use detailed data on U.S. "Other Private Services" from 31 countries $^{1}$ and 14 industries $^{2}$ that appear in the U.S. International Transactions Accounts compiled by the

\footnotetext{
${ }^{1}$ Belgium-Luxembourg, South Africa, France, Israel, Germany, Australia, Italy, China, Netherlands, Hong Kong, Norway, India, Spain, Indonesia, Sweden, Japan, Switzerland, Korea, United Kingdom, Malaysia, Argentina, New Zealand, Brazil, Philippines, Chile, Singapore, Mexico, Taiwan, Venezuela, Thailand, and Bermuda.

${ }^{2}$ Education; financial services; telecommunications; advertising; computer and data processing services; database and other information services; research, development, and testing services; management, consulting, and public relations; legal services; construction, engineering, architecture, and mining; industrial engineering; installation, maintenance, and repair of equipment; other business, professional, and technical services; and other services.
} 


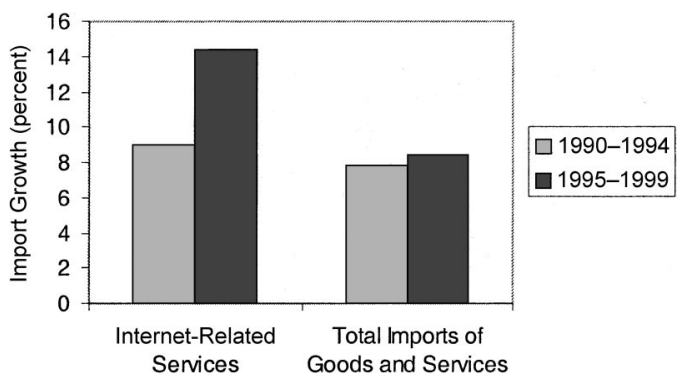

Figure 1. AnNual U.S. Import Growth

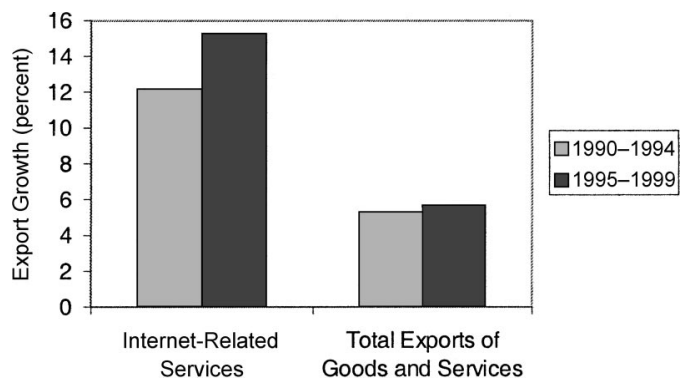

Figure 2. Annual U.S. Export Growth
Bureau of Economic Analysis (U.S. Department of Commerce, 2000). "Other Private Services" are primarily business services, and in 1999 they made up 27 percent of total service imports and 38 percent of total service exports in the United States. The remaining share of total services trade is composed of payments for transportation, royalties, and license fees.

The disaggregated data on business services are available only for trade among unaffiliated parties (i.e., the data exclude intra-firm trade, such as trade between IBM and one of its subsidiaries abroad). Although intra-firm trade is important (accounting for about 35 percent of U.S. trade in business services from 1995 to 1999), it is determined by different forces and should therefore be studied separately. In particular, affiliated-party trade is by definition dependent on direct investment and is therefore greatest in industries and countries where direct investment is large. We hypothesize that this omission will bias our analysis against finding a strong role for the Internet, as many of the difficulties of foreign service provision over the web, such as monitoring, communication, and security, can be overcome in a sharedownership environment.

Examining the growth of services trade by industry provides some evidence that the Internet has stimulated trade in recent years. Figures 1 and 2 show U.S. nominal trade growth in total goods and services (excluding oil and agriculture) and Internet-related services, which consist of services that can be transferred electronically. ${ }^{3}$ From 1995 to 1999 , expansion of trade in

\footnotetext{
${ }^{3}$ Internet-related services include accounting, auditing, and bookkeeping; database and other information services;
}

Internet-related services has been very rapid as compared with the previous four-year period and has far outpaced growth of overall goods and services. Moreover, one of the fastest-growing categories of services over this period was "computer and data processing." U.S. exports of computing services grew 71 percent between 1995 and 1999, while U.S. imports grew 243 percent.

The United States is also by far the world leader in Internet usage, so if there is an effect of the Internet on trade it is likely to show up in U.S. data. To measure Internet penetration we use data on the number of top-level domain names attributed to each country from the Internet Software Consortium (ISC). A top-level domain name is either an ISO country code or one of the generic domains (com/org/net/etc). ${ }^{4}$ In our sample, the number of host sites in a country increased rapidly from, on average, 49,000 in 1995 to 378,000 in 1999. There is also a lot of variation in the data: the standard deviation of the host variable was 68,000 in 1995 and 517,000 in $1999 .{ }^{5}$

\footnotetext{
$\overline{\text { legal services; research, development, and testing; computer }}$ and data processing; financial services; and management, consulting, and public relations.

${ }^{4}$ A site's domain name does not necessarily correspond to where it is located. However, in Freund and Weinhold (2000) we argue that, even if a Venezuelan domain name, for example, is located in another country, it is likely that the content of the site is aimed at Venezuelans. In all of the specification reported in the paper, we do not attribute hosts under the domains ".org," ".edu," ".net," ".com,” or ".int" to any particular country.

${ }^{5}$ In the regressions reported, the Internet variable is not scaled. While this may overstate Internet intensity in large countries, scaling the variable by population is likely to understate the importance of the Internet in large countries like India and China. In robustness checks, the results were qualitatively similar if we used the variable scaled by population.
} 


\section{Empirical Evidence}

Previous empirical work finds that movements in economic activity and the real exchange rate are the most important determinants of services trade flows (William Helkie and Lois Stekler, 1987; Juann Hung and Sandra Viana, 1995; Alan Deardorff et al., 2000). Using these insights, we construct two models of services trade. In the first model, the dependent variable is the growth of U.S. trade in 14 service industries from 1995 to 1999. Services trade growth is regressed on industry fixed effects, the Internet variable, GDP growth, realexchange-rate appreciation, and the initial level of trade. ${ }^{6}$ We use the log-level of the Internet variable at the end of the period because it is a new technology and all of the growth in the Internet should contribute to trade over this period. We distinguish between exports and imports in the regression equations because foreign growth and exchange-rate movements are likely to affect them in different ways. We expect that GDP growth abroad will positively impact U.S. export growth because of increased demand for services in these countries. U.S. import growth is also likely to be positively impacted if GDP growth abroad is associated with a greater supply of these service industries. A real appreciation of the dollar would be expected to increase U.S. imports in the long run, but it could lower the nominal value of imports in the short run, as the price of services decreases for a given quantity demanded (the Jcurve effect). We include the log of the initial value of trade to allow for more rapid adjustment when levels are low.

As shown in Table 1, the effect of the Internet on services trade growth is positive and significant. Countries that have greater Internet penetration also have had higher growth in services trade in recent years. Specifically, for all service industries we find that a 10percent increase in the level of the Internet variable is associated with a 1.7-percentagepoint increase in the growth of U.S. imports and a 1.1-percentage-point increase in the growth of

\footnotetext{
${ }^{6}$ Trade and GDP are from the World Bank's World Development Indicators. The real exchange rate is from the IMF's International Financial Statistics.
}

TABle 1-Growth OF U.S. IMPORTS AND U.S. EXPORTS, VARIOUS SERVICES, 1995-1999

A. U.S. Import Growth, 1995-1999

\begin{tabular}{lccc} 
& \multicolumn{3}{c}{ Services } \\
\cline { 2 - 4 } & $\begin{array}{c}\text { All } \\
\text { Independent variable }\end{array}$ & $\begin{array}{c}\text { BPT }^{\mathrm{a}} \\
\text { (ii) }\end{array}$ & $\begin{array}{c}\text { All } \\
\text { (iii) }\end{array}$ \\
\hline Log Internet variable & 0.17 & 0.23 & 0.17 \\
& $(4.06)$ & $(3.76)$ & $(2.24)$ \\
GDP growth & 1.71 & 1.97 & 1.58 \\
& $(3.89)$ & $(4.00)$ & $(3.22)$ \\
Real-exchange appreciation & 0.76 & 1.04 & 0.59 \\
& $(1.85)$ & $(2.52)$ & $(1.30)$ \\
Log trade in 1995 & -0.30 & -0.39 & -0.32 \\
& $(-6.70)$ & $(-5.81)$ & $(-6.63)$ \\
Log GDP in 1995 & & & 0.03 \\
& & & $(0.28)$ \\
Log population in 1995 & & & 0.02 \\
& & & $(0.31)$ \\
Financial depth & & & $(0.26)$ \\
& & & 361 \\
\hline No. observations: & 361 & 239 & 0.24 \\
$R^{2}$ : & 0.24 & 0.22 &
\end{tabular}

B. U.S. Export Growth, 1995-1999

\begin{tabular}{|c|c|c|c|}
\hline \multirow[b]{2}{*}{ Independent variable } & \multicolumn{3}{|c|}{ Services } \\
\hline & $\begin{array}{l}\text { All } \\
\text { (iv) }\end{array}$ & $\begin{array}{l}\mathrm{BPT}^{\mathrm{a}} \\
(\mathrm{v})\end{array}$ & $\begin{array}{l}\text { All } \\
\text { (vi) }\end{array}$ \\
\hline Log Internet variable & $\begin{array}{c}0.11 \\
(3.79)\end{array}$ & $\begin{array}{c}0.14 \\
(3.03)\end{array}$ & $\begin{array}{c}0.06 \\
(1.15)\end{array}$ \\
\hline GDP growth & $\begin{array}{c}0.84 \\
(2.93)\end{array}$ & $\begin{array}{l}1.04 \\
(2.65)\end{array}$ & $\begin{array}{c}0.62 \\
(1.94)\end{array}$ \\
\hline Real-exchange appreciation & $\begin{array}{c}0.42 \\
(1.50)\end{array}$ & $\begin{array}{c}0.72 \\
(1.85)\end{array}$ & $\begin{array}{c}0.18 \\
(0.64)\end{array}$ \\
\hline Log trade in 1995 & $\begin{array}{c}-0.25 \\
(-6.11)\end{array}$ & $\begin{array}{c}-0.30 \\
(-5.47)\end{array}$ & $\begin{array}{c}-0.30 \\
(-6.67)\end{array}$ \\
\hline Log GDP in 1995 & & & $\begin{array}{c}0.16 \\
(1.75)\end{array}$ \\
\hline Log population in 1995 & & & $\begin{array}{c}-0.00 \\
(-0.09)\end{array}$ \\
\hline Financial depth & & & $\begin{array}{c}-0.09 \\
(-1.35)\end{array}$ \\
\hline No. observations: & 394 & 253 & 394 \\
\hline$R^{2}:$ & 0.25 & 0.26 & 0.28 \\
\hline
\end{tabular}

Notes: Industry fixed effects were included in all regressions (not shown). Table entries are regression coefficients, with heteroskedasticity-consistent $t$ statistics in parentheses.

${ }^{\mathrm{a}} \mathrm{BPT}=$ business, professional, and technical services.

U.S. exports from 1995 to 1999. If this dynamic relationship were to continue to hold over the long run, it would imply that a 10-percent increase in the Internet variable abroad is associated with about a 6-percent increase in the level 
of U.S. imports and about a 4-percent increase in the level of U.S. exports. We also estimate the regression equation on a subset of industries called "Business, Professional, and Technical Services," which exclude telecommunications, education, and financial services. The results are even stronger for this subcategory.

It is important to note that, while our results imply that there is a correlation between Internet adoption and international services trade, they say little about causality. Using the twice-lagged Internet variable in the regression equation yields similar results (not reported), suggesting that Internet development promotes services trade. However, causality probably runs both ways: increasing trade in services leads firms to adopt the Internet to facilitate that trade, and greater Internet penetration causes firms to use the Internet for trade in services.

Apart from endogeneity, it is also possible that the Internet is not actually correlated with services trade, but that the Internet variable is correlated with important variables for trade growth that are omitted from the regression equation. In particular, countries with higher per capita incomes might have experienced greater trade growth over this period, and the Internet variable might be a good proxy for relative income; or the Internet variable could be correlated with comparative advantage in service production. To control for country size or income effects, we include the log of the initial value of GDP and population. We also include a measure of financial depth, M2/GDP (calculated from the IMF's International Financial Statistics), to proxy for overall comparative advantage in services across countries. The intuition is that a country with a deeper financial system is likely to have a labor force that is skilled in electronic services and has a demand for such services.

Columns (iii) and (vi) of Table 1 report the results when these variables are included. We find that GDP, population, and financial depth are not significant in the U.S. import-growth equation, and the coefficient on the Internet variable remains unchanged and highly significant. The coefficient on the Internet variable in the U.S. export equation, however, declines to about half of its previous value. The log level of GDP is significant at the 10-percent level, suggesting that part of the significance of the In-
Table 2-Gravity Equations of the LeVel of Trade, VARIOUS SERVICES, 1995-1999

\begin{tabular}{lccccc}
\hline \hline & \multicolumn{2}{c}{ Log U.S. imports } & Log U.S. exports \\
\cline { 2 - 3 } \cline { 5 - 6 } & All & & All & \\
& services & BPT $^{\mathrm{a}}$ & services & BPT $^{\mathrm{a}}$ \\
& (i) & (ii) & (iii) & (iv) \\
\hline Log Internet & 0.05 & 0.12 & -0.02 & -0.01 \\
variable & $(1.60)$ & $(3.04)$ & $(-0.80)$ & $(-0.31)$ \\
Financial depth & 0.34 & 0.45 & 0.30 & 0.41 \\
& $(5.12)$ & $(5.70)$ & $(5.10)$ & $(5.06)$ \\
Log GDP & 0.78 & 0.68 & 0.73 & 0.75 \\
& $(12.38)$ & $(8.80)$ & $(13.23)$ & $(9.88)$ \\
Log population & -0.09 & -0.04 & -0.11 & -0.11 \\
& $(-2.23)$ & $(-0.83)$ & $(-3.01)$ & $(-2.13)$ \\
Log distance & -0.39 & -0.42 & -0.08 & -0.08 \\
& $(-5.14)$ & $(-4.81)$ & $(-1.10)$ & $(-0.85)$ \\
Common language & 0.49 & 0.46 & 0.07 & 0.02 \\
& $(6.93)$ & $(5.50)$ & $(1.20)$ & $(0.24)$ \\
Adjacency & 0.61 & 0.40 & 1.29 & 1.21 \\
& $(3.63)$ & $(2.12)$ & $(8.88)$ & $(6.85)$ \\
\hline \multirow{2}{*}{ No. observations: } & 1,977 & 1,289 & 2,056 & 1,328 \\
$R^{2}$ : & 0.71 & 0.63 & 0.67 & 0.59 \\
\hline
\end{tabular}

Notes: Industry and year fixed effects included in all regressions (not shown). Table entries are regression coefficients, with heteroskedasticity-consistent $t$ statistics in parentheses.

${ }^{\mathrm{a}} \mathrm{BPT}=$ business, professional, and technical services.

ternet variable in the base regression is due to a correlation between the Internet variable and income, and that higher-income countries have experienced faster import growth.

The second regression that we estimate is a modified gravity equation of services trade. A basic gravity equation depicts trade between countries as proportional to the product of their economic masses (GDP's) and inversely related to the distance between them. Using panel data from 1996 to 1999, we regress log levels of exports and imports on the logs of income and population of the partner country, the log of distance to the United States, indicator variables for adjacency and sharing a common language, and industry and year fixed effects. ${ }^{7} \mathrm{We}$ also include the index of financial depth and the log of the Internet variable.

The results, reported in Table 2, provide further evidence of an effect of the Internet on U.S. imports of services. In particular, a 10-percent

\footnotetext{
${ }^{7}$ See Freund and Weinhold (2000) for a detailed description of the additional data.
} 
increase in Internet penetration abroad leads to about a 1.2-percent increase of U.S. imports in business, professional, and technical services. We do not find evidence that Internet penetration abroad has increased U.S. exports of services. However, one problem with the export equation is that we do not control for trade policy, and it is likely that there are vast trade policy differences abroad that affect the crosssectional distribution of U.S. services exports. ${ }^{8}$ U.S. import data, on the other hand, do not suffer from this problem, since all countries face the same U.S. regulations on their exports.

\section{Conclusion}

Our results suggest that Internet development abroad has already begun facilitating increased exports of services to the United States. Specifically, we find that the short-run impact is about a 1.7-percentage-point boost to growth for a 10-percent increase in the Internet variable.

The expansion of trade in services has important implications for growth around the world. The standard gains from trade can be expected: Resources will be reallocated to their most productive uses and welfare will increase. Moreover, there are likely to be large multipliers on these effects, as other studies have found that services are important inputs into nearly all sectors (Se Hark Park and Kenneth S. Chan, 1989). This implies that, while the Internet will affect growth directly through its impact on productivity, it should also increase growth indirectly via its effect on openness.

\footnotetext{
${ }^{8}$ See Bernard Hoekman and Carlos Primo Braga (1997) and Gary C. Hufbauer and Tony Warren (1999) for evidence on protection in services.
}

\section{REFERENCES}

Deardorff, Alan; Hymans, Saul; Stern, Robert M. and Xiang, Chong. "Forecasting U.S. Trade in Services." Mimeo, University of Michigan, 2000.

Freund, Caroline and Weinhold, Diana. "On the Effect of the Internet on International Trade." Board of Governors of the Federal Reserve System International Finance Discussion Paper No. 693, 2000.

Helkie, William and Stekler, Lois. "Modeling Investment Income and Other Services in the U.S. International Transactions Accounts." Board of Governors of the Federal Reserve System International Finance Discussion Paper No. 319, 1987.

Hoekman, Bernard and Primo Braga, Carlos. "Protection and Trade in Services." World Bank Policy Research Working Paper No. 1747, 1997.

Hufbauer, Gary C. and Warren, Tony. "The Globalization of Services." Institute for International Economics (Washington, DC) Working Paper, October 1999.

Hung, Juann and Viana, Sandra. "Modeling U.S. Services Trade Flows: A CointegrationECM Approach." Federal Reserve Bank of New York Research Paper No. 9518, 1995.

Park, Se Hark and Chan, Kenneth S. "A CrossCountry Input-Output Analysis of Intersectoral Relationships between Manufacturing and Services." World Development, February 1989, 17(2), pp. 199-212.

U.S. Department of Commerce. "U.S. International Services: Cross Border Trade in 1999 and Sales Through Affiliates in 1998." Survey of Current Business, October 2000, 80(10), pp. 119-61. 